\title{
Applying the Equivalent Plane Strain solution to design the soft soil improvement by vertical drains
}

\author{
$\mathrm{Nu}$ Thi Nguyen \\ Faculty of Geosciences and Geoengineering, Hanoi University of Mining and Geology, Vietnam
}

\begin{tabular}{|c|c|}
\hline ARTICLE INFO & ABSTRACT \\
\hline $\begin{array}{l}\text { Article history: } \\
\text { Received } 01^{\text {st Feb. } 2020} \\
\text { Revised } 23^{\text {rd }} \text { May } 2020 \\
\text { Accepted } 30^{\text {th }} \text { June } 2020\end{array}$ & $\begin{array}{l}\text { The soft soil improvement by vertical drains (PVD, sand drains) are widely } \\
\text { used in Vietnam. One of the methods is used for designing soft soil } \\
\text { improvement by vertical drains is the Equivalent Plane Strain solution. To } \\
\text { use this solution, the permeability coefficient of soil is converted into the }\end{array}$ \\
\hline $\begin{array}{l}\text { Keywords: } \\
\text { Consolidation, } \\
\text { Sand drains, } \\
\text { Soft soil, }\end{array}$ & $\begin{array}{l}\text { equivalent permeability under plane strain. The paper presents the } \\
\text { application of this solution to design soft soil improvement by sand drains } \\
\text { at Km } 3+130 \text { Vi Thanh - Can Tho. It indicated that the settlement results } \\
\text { of the soft ground treatment design based on Equivalent Plane Strain } \\
\text { solution are similar to those from the Axisymmetric Condition analysis } \\
\text { and field monitoring. }\end{array}$ \\
\hline
\end{tabular}

Copyright (C) 2020 Hanoi University of Mining and Geology. All rights reserved.

\section{Introduction}

The soft soil improvement by vertical drains has been widely applied in the world (Perera et al, 2017) as well in Vietnam (Nguyen Thi Nu, 2016b). In order to design vertical drains, Barron (1948) and Hansbo (1981) were propsosed the consolidation theory of single wells. However, there are some disadvantages of this analysis, such as the effect of the depth of the well was not taken, the difference in compressibility of soil environment and materials in the sand well were ignored, etc. In designing the soft soil improvement by sand drains, the total settlement of the treated soil was determined by the

${ }^{*}$ Corresponding author

E-mail: nguyenthinu@humg.edu.vn

DOI: 10.46326/JMES.2020.61(3).01 approximate Evgenev's equation (Hoang Van Tan et al., 1977) and the results were unreliable. Moreover, the method of calculating the total settlement on the Vietnamese standard 22TCN262-2000 was only mentioned the drainage ability of the sand drains, but not any decrease in settlement when treating the ground with sand drains, nor ignorance of the hardness of sand drains.

Currently, in order to design soft soil improvement by vertical drains, the finite element method by using Equivalent Plane Strain solution is being applied by some authors in the world (Perera et al, 2017). In oder to use Equivalent Plane Strain solution, it is necessary to convert Axisymmetric Condition analysis into Equivalent Plane Strain analysis, and it must be simulated the actual working conditions of the ground. The transition between these analyses was solved by Hird et al. (1992). However, this method ignored 
the effects of disturbance and resistance of the well. Indraratna and Redana (1997) developed this theory in the case of the analysis of soft soil improvement by vertical drains and took into the well drainage factor. Indraratna et al., (2005a,b,c) proposed the theory of consolidation in the case of soft soil improvement by vertical drains incorporating with surcharge and vacuum preloading and the method to convert Axisymmetric Condition analysis into Equivalent Plane Strain solution. This theory has been proved by the these authors with actual practical works.

In Vietnam, soft soil is widely distributed in most of deltas and needs to be improved by many methods (Nhu Viet Ha, 2020, Nguyen Thi Nu, 2020a, 2020b, Nguyen Thi Nu and Phi Hong Thinh, 2020; Nguyen Thi Nu et al., 2019, Nguyen Thi Nu et al., 2019). The Equivalent Plane Strain solution has not been studied and applied to the practice of soft soil treatment in Vietnam. Therefore, the article aimed at introducing the Equipment Plane Strain analysis of Indraratna et al. (2005a,b,c) and applying this method to design the improvement of soft soil by sand drains in a case study of Vietnam.

\section{Equivalent Plane Strain solution to design soft soil improvement by vertical drains}

\subsection{Equivalent Plane Strain solution in case of soft soil improvement by vertical drains}

In order to design soft soil improvement by vertical drains using the finite element method with the application geotechnical software such as Plaxis 8.2, Indraratna and Redana (1997) converted Barron and Hansbo's Axisymmetric solution into Equivalent Plane Strain solution.

Indraratna and Redana (1997) indicated that the average degree of consolidation $\left(\overline{U_{h p}}\right)$ on a horizontal plane at the depth $\mathrm{z}$ and at time $\mathrm{t}$ can be predicted from:

$$
\overline{U_{h_{p}}}=1-\frac{\bar{u}}{\overline{u_{0}}}=1-\exp \left(\frac{-8 T_{h p}}{\mu_{p}}\right)
$$

Where $\overline{u_{0}}$ - the initial excess pore water pressure; $\bar{u}$ - the excess pore water pressure at $t$; $T_{h p}$ - the time factor for plane strain condition.

$$
\mu_{p}=\left[\alpha+\beta \frac{k_{h p}}{k_{h p}^{\prime}}+\theta\left(2 l . z-z^{2}\right)\right]
$$

$$
\begin{gathered}
\alpha=\frac{2}{3}-\frac{2 b_{s}}{B}\left(1-\frac{b_{s}}{B}+\frac{b_{s}^{2}}{3 B^{2}}\right) \\
\beta=\frac{1}{B^{2}}\left(b_{s}-b_{w}\right)^{2}+\frac{b_{s}}{3 B^{2}}\left(3 b_{w}^{2}-b_{s}^{2}\right) \\
\theta=\frac{2 k_{h p}^{2}}{k^{\prime}{ }_{h p} q_{z} B}\left(1-\frac{b_{w}}{B}\right)
\end{gathered}
$$

Where $B, b_{s}, b_{w}$ - the haft of the width of plane strain unit cell, the width of the drain, and the width of the smear zone, respectively; $k_{h p}$ and $k_{h p}^{\prime}$ - the smear zone permeability and the undisturbed permeability for plane strain conditions respectively; $l$ - the length of drain well; $q_{z}$ - the drain discharge capacity in plane strain condition; $p$ - the indicated the plane strain condition.

The average degree of consolidation for axisymmetric $\left(\overline{U_{h}}\right)$ condition is equal to the average degree of consolidation for plane strain $\left(\overline{U_{h p}}\right)$ condition at each time step and at a given stress level (Figure 1):

$$
\left(\overline{U_{h}}\right)=\overline{\left(U_{h p}\right)}
$$

The equivalent permeability under plane strain in undisturbed zone is converted from Axisymmetric condition can be determined as follows:

$$
\begin{array}{r}
\frac{k_{h p}}{k_{h}}=\frac{\left[\alpha+\beta \frac{k_{h p}}{k^{\prime} h p}+\theta\left(2 l . z-z^{2}\right)\right]}{\left[\ln \left(\frac{n}{s}\right)+\frac{k_{h}}{k_{h}} \ln (s)-\frac{3}{4}+\pi\left(2 l \cdot z-z^{2}\right) \frac{k_{h}}{q_{w}}\right]} \\
\frac{k^{\prime} h p}{k_{h p}}=\frac{\beta}{\frac{k_{h p}}{k_{h}}\left[\ln \left(\frac{n}{s}\right)+\frac{k_{h}}{k^{\prime} h} \ln (s)-\frac{3}{4}\right]-\alpha}
\end{array}
$$

Where $n=B / b_{w} ; s=b_{s} / b_{w} ; q_{w^{-}}$the drain discharge capacity; $k_{h}$ - the horizontal permeability coefficient of undisturbed zone; $k_{h}^{\prime}$ - the horizontal permeability coefficient of smear zone.

In case of neglecting well resistance and the smear effect, the ratio of equivalent permeability under plane strain and the Axisymmetric permeability in undisturbed zone can be determined as follows (Hird et al.,1992):

$$
\frac{k_{h p}}{k_{h}}=\frac{0,67}{[\ln (n)-0,75]}
$$

The drain discharge capacity under plane strain was converted as following equation:

$$
q_{z}=\frac{2}{\pi B} q_{w}
$$




\subsection{Equivalent Plane Strain solution in case of soft soil improvement by vertical drains incorporating with surcharge and vacuum preloading}

Indraratna et al. (2005) established the Equivalent Plane Strain solution in case of soft soil improvement by vertical drains incorporating with surcharge and vacuum preloading based on following assumptions:

- Soil is fully saturated and homogenous, lamina flow thorough the soil based on Darcy's law. At the outer boundary of the unit cell, there is not flow of water, and for the relatively long vertical drains, only the radial flow is permitted to occur.

- Soil strain is uniform at the boundary of unit cell and the small strain theory is valid (Barron, 1948). The ratio of horizontal permeability coefficient of smear zone and horizontal permeability coefficient of undisturbed zone is constant during the consolidation process.

- During the consolidation process, the relationship between the average void ratio and logarithm of average effective stress in normally consolidated range was expressed as follows (Figure 2a):

$$
\bar{e}=e_{0}-C_{c} \log \left(\frac{\sigma^{\prime}}{\sigma_{i}}\right)
$$

If current vertical effective stress is smaller than the preconsolidation pressure $\left(P_{c}\right)$, the compression index $C_{c}$ was replaced by the recompression index $C_{r}$.

- For radial drainage, the horizontal coefficient of permeability of soil decreases with the average void ratio (Figure $2 \mathrm{~b}$ ) as follows:

$$
\bar{e}=e_{0}+C_{k} \log \left(\frac{k_{h}}{k_{h i}}\right)
$$

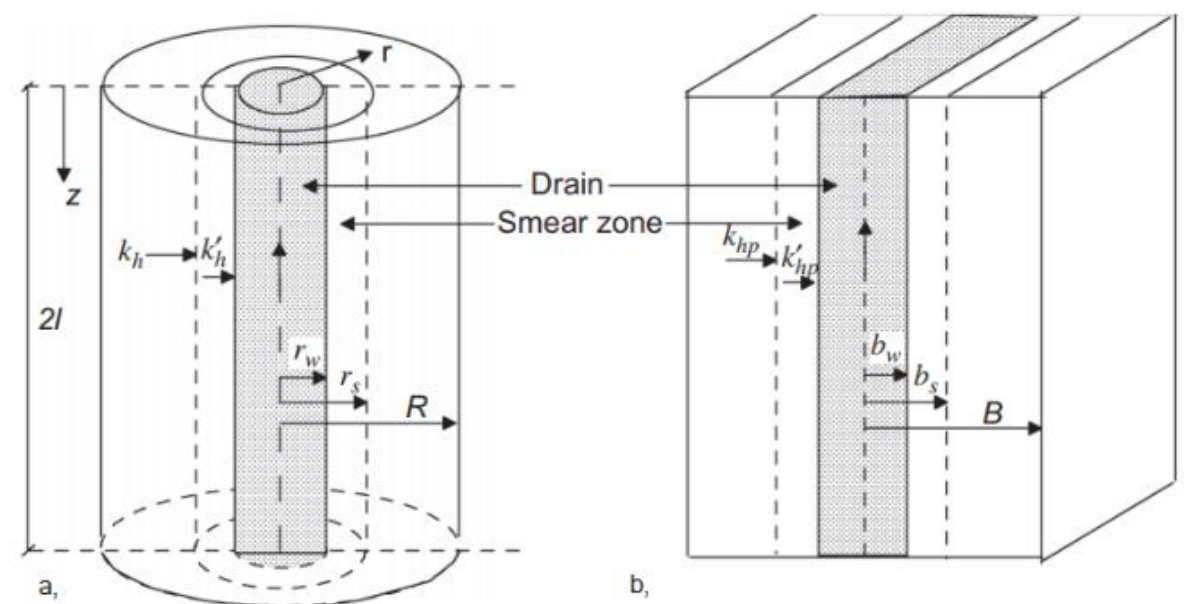

Figure 1. Conversion of an axisymmetric unit cell into plane strain condition:

(a) axisymmetric; (b) plane strain (Indraratna và Redana ,1997).

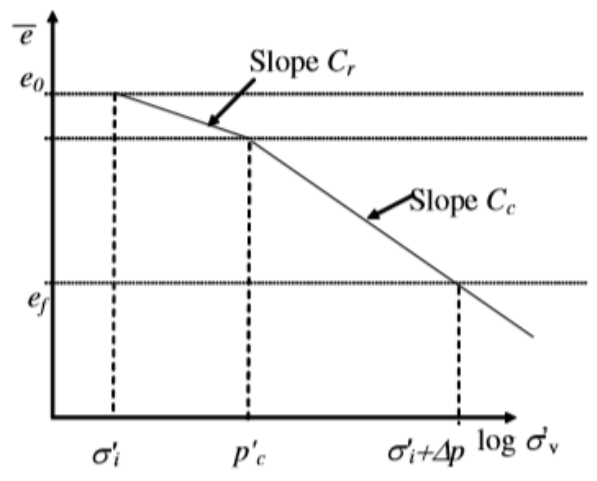

a, Soil compression curve

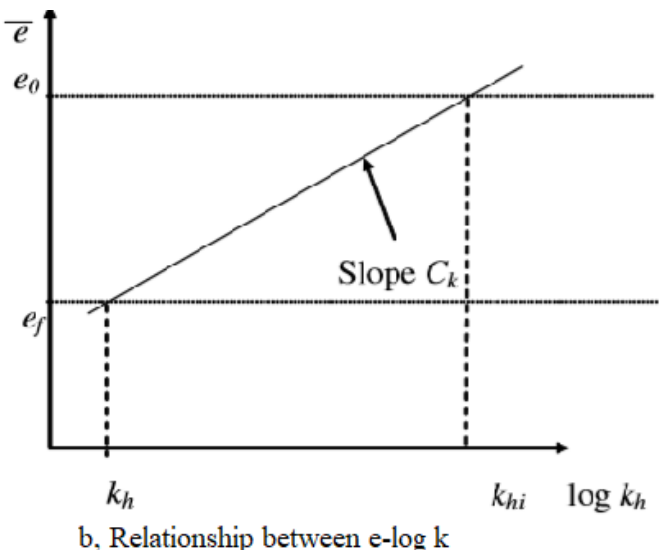

b, Relationship between e-log $\mathrm{k}$

Figure 2. a. Soil compression curve e-log $\sigma^{\prime}$; b. Relationship between e-log $k_{h}$ (Indraratna, 2005c, 2008). 
- The distribution of vacuum pressure along boundary of the drain is considered to vary linearly from - $p_{0}$ to $-k_{1} p_{0}$ (Figure 3 ), where $k_{1}$ is the ratio of the vacuum pressure at the top and the bottom of vertical drains.

In case of Axisymmetric Condition analysis, the dissipation rate of average excess pore pressure ration $R_{u}=\overline{u_{t}} / \Delta p$ at any dimensionless time factor for horizontal drainage $T_{h}$ was calculated as follows:

$$
\begin{gathered}
R_{u}=\left(1+\frac{p_{0}}{\Delta p} \frac{\left(1+k_{1}\right)}{2}\right) \exp \left(-\frac{8 T_{h} *}{\mu}\right)- \\
\frac{p_{0}}{\Delta p} \frac{\left(1+k_{1}\right)}{2}
\end{gathered}
$$

where $T_{h}{ }^{*}$ - the modified time factor,

$$
T_{h}{ }^{*}=P_{a v}{ }^{*} T_{h}
$$

$\Delta p$ - the preloading pressure; $T_{h}$ - the dimensionless time factor for horizontal drainage;

$$
\begin{gathered}
T_{h}=\frac{c_{h i} t}{d_{e}^{2}} \\
P_{a v}=0,5\left[1+\left(1+\Delta p / \sigma_{i}^{\prime}+p_{0}(1\right.\right. \\
\left.\left.\left.+k_{1}\right) / 2 \sigma_{i}^{\prime}\right)^{1-C_{c} / C_{k}}\right]
\end{gathered}
$$

$\mu$ - the parameter indicating the geometry of vertical drains system and smear effect;

$$
\begin{aligned}
\mu= & \frac{\mathrm{n}^{2}}{\mathrm{n}^{2}-1}\left[\ln \left(\frac{\mathrm{n}}{\mathrm{s}}\right)+\frac{\mathrm{k}_{\mathrm{h}}}{\mathrm{k}_{\mathrm{h}}^{\prime}} \ln (\mathrm{s})-\frac{3}{4}\right]+\frac{\mathrm{s}^{2}}{\mathrm{n}^{2}-1} \times \\
& \left(1-\frac{\mathrm{s}^{2}}{4 \mathrm{n}^{2}}\right)+\frac{\mathrm{k}_{\mathrm{h}}}{\mathrm{k}_{\mathrm{h}}} \frac{1}{\mathrm{n}^{2}-1}\left(\frac{\mathrm{s}^{4}-1}{4 \mathrm{n}^{2}}-\mathrm{s}^{2}+1\right)
\end{aligned}
$$

$$
\begin{gathered}
n=\frac{d_{e}}{d_{w}} \\
s=\frac{d_{s}}{d_{w}} \\
c_{h i}=\frac{k_{h i} \gamma_{w}}{m_{v i}}
\end{gathered}
$$

$C_{h i}$ - the horizontal coefficient of consolidation of soil; $m_{v i}$ - the coefficient of volume compressibility; $\gamma_{w}$ - the unit weigh of water.

In case of ignoring the smear effect:

$$
\mu=\ln \left(\frac{n}{s}\right)+\frac{k_{h}}{k_{h}^{\prime}} \ln (s)-\frac{3}{4}
$$

In case of ignoring well resistance and the smear effects:

$$
\mu=\ln (n)-\frac{3}{4}
$$

If $C_{c} / C_{k}=1$ and $p_{0}=0$, equation (13) is similar to the Hansbo equation (Hansbo, 1981):

$$
R_{u}=\exp \left(-\frac{8 T_{h} *}{\mu}\right)
$$

The average horizontal degree of consolidation at any time can be calculated as following equation:

$$
U_{h}=\frac{1-R_{u}}{1-R_{u, t=\infty}} 100
$$

In case of plane strain analysis, Indraratna et al. (2005) expressed the ratio of the average

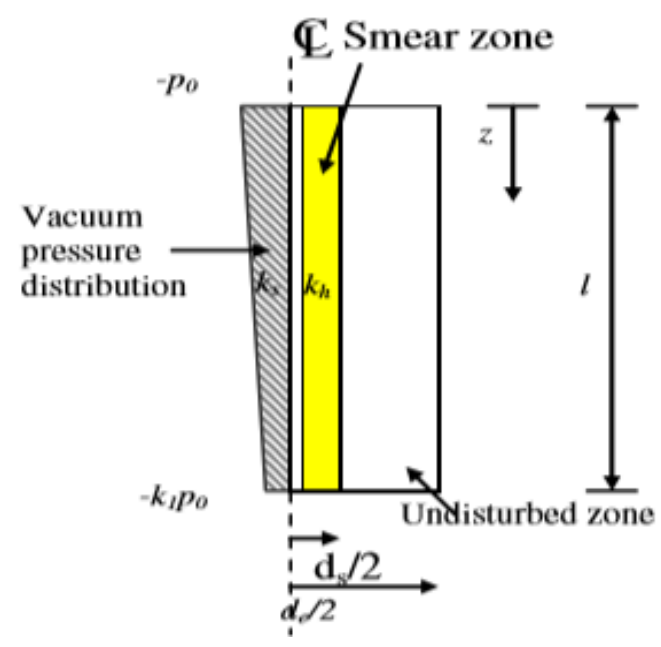

Figure 3. Cylindrical unit cell with linear vacuum pressure distribution (Indraratna, 2008). 
excess pore pressure $\frac{\overline{u_{p}}}{\Delta p}$ for radial drainage incorporation vacuum preloading as follows:

$$
\begin{gathered}
\frac{\overline{u_{p}}}{\Delta p}=\left(1+p_{o} \frac{\left(1+k_{1}\right)}{2 \Delta p}\right) \exp \left(-\frac{8 T_{h p}}{\mu_{p}}\right) \\
-\frac{p_{0}}{\Delta p} \frac{\left(1+k_{1}\right)}{2} \\
\text { where } \mu_{p}=\left[\alpha+\frac{k_{h p}}{k^{\prime} h p} \ln (\beta)+\theta\right] \\
\alpha=\frac{2}{3} \frac{(n-s)^{3}}{n^{2}(n-1)} \\
\beta=\frac{2(s-1)}{n^{2}(n-1)}[n(n-s-1) \\
\left.+\frac{1}{3}\left(s^{2}+s+1\right)\right] \\
\theta=\frac{4 k_{h p}}{3 B q_{z}}\left(1-\frac{1}{n}\right) l^{2} \\
n=\frac{B}{b_{w}} \\
s=\frac{b_{s}}{b_{w}}
\end{gathered}
$$

In case of the plane strain condition for vertical drains incorporating with vacuum preloading (no preloading), the average excess pore pressure $\bar{u}$ at time tis expressed as follows:

$$
\begin{gathered}
\bar{u}=\left(1+\frac{\left(1+k_{1}\right) p_{0}}{2}\right) \exp \left(-\frac{8 T_{h p}}{\mu_{p}}\right) \\
-\frac{\left(1+k_{1}\right) p_{0}}{2}
\end{gathered}
$$

As shown in Figure 1, the average degree of consolidation for Axisymmetric $\left(\overline{U_{h}}\right)$ condition is equal to the average degree of consolidation for planee strain $\left(\overline{U_{h p}}\right)$ condition at each time step and at a given stress level:

$$
\left.\left(\overline{U_{h}}\right)=\overline{\left(U_{h p}\right.}\right)
$$

The equivalent permeability under plane strain in undisturbed zone is converted from Axisymmetric condition can be determined as follows:

$$
\frac{k_{h p}}{k_{h}}=\frac{\left[\alpha+\frac{k_{h p}}{k^{\prime} h p} \ln (\beta)+\theta\right]}{\left[\ln \left(\frac{n}{s}\right)+\frac{k_{h}}{k^{\prime} h} \ln (s)-\frac{3}{4}+\pi \frac{2 k_{h}}{3 q_{w}} l^{2}\right]}
$$

The equivalent permeability within the smear zone can be calculated by:

$$
\frac{k^{\prime} h p}{k_{h p}}=\frac{\beta}{\frac{k_{h p}}{k_{h}}\left[\ln \left(\frac{n}{s}\right)+\frac{k_{h}}{k_{h} h} \ln (s)-\frac{3}{4}\right]-\alpha}
$$

In case of neglecting the smear effect, the ratio of equivalent permeability under plane strain and the Axisymmetric permeability in undisturbed zone can be determined as follows:

$$
\begin{aligned}
\frac{k_{h p}}{k_{h}}=\frac{\frac{2}{3} \frac{(n-1)^{2}}{n^{2}}}{[\ln (n)-0,75]} & \\
& \approx \frac{0,67}{[\ln (n)-0,75]}
\end{aligned}
$$

To apply the Equivalent Plane Strain solution to design soft soil improvement by sand drains, Plaxis 8.2 software 2D version was used. This software uses finite element method to solve geotechnical problems (Brinkgreve, 2002). To use this solution, the ground is divided into element grids, based on the force balancing method through the relationship between stress and strain, the displacement of element nodes, stress state, and deformation of the soil ground were determined.

\section{Applying the Equivalent Plane Strain solution to design soft soil improvement by sand drains}

\subsection{Designing soft soil improvement by sand drains}

The project of construction road on soft soil at $\mathrm{Km} 3+130$ of the road connecting Vi Thanh town to Can Tho city, Vietnam. The parameters of road include the width of embankment of $11.8 \mathrm{~m}$, slope factor of 1:2, and the height of embankment of $4.8 \mathrm{~m}$. The road embankment was designed in two stages. At the first one, the time of construction was 40 days, the speed of construction was $10 \mathrm{~cm} /$ day, and the time for consolidation was 60 days; those in the stage 2 were 30 days, $6 \mathrm{~cm} /$ day, and 120 days respectively. The total construction time for two stages was 250 days.

The soil profile including three layers as following:

Layer 1: Very soft soil with the thickness of 14 $\mathrm{m}$;

Layer 2: Stift clay with the thickness of $6.0 \mathrm{~m}$; 
Layer 3: Very stiff clay with the thickness of $10 \mathrm{~m}$.

The timewater was at the depth of $4.0 \mathrm{~m}$ under the surface. The soft soil samples were taken from the boreholes and the properties of soil layers were determined at the Geotechnical Laboratory of Department of Engineering Geology, Ha Noi University of Mining and Geology. The horizontal coefficient of permeability was determined by Rowe cell (Nguyen Thi Nu et al 2011; Nguyen Thi Nu, 2014, 2016a, 2016b). The effective cohesion and effective internal friction angle was determined by consolidated undrained triaxial compression tests (CU test). The horizontal permeability coefficient of the soft soil improvement by sand drains was calculated based on the Equivalent Plane Strain solution. The physico - mechanical properties are presented in Table 1.

The soft soil was improved by sand drains. The parameters of sand drains are provided in Table 2.

In order to design the improvement soft soil by sand drains, the standard calculation method (22TCN262-2000) and the Equipment Plane Strain solution on Plaxis 8.2 software 2D version were used. During the improvement of soft soil, the settlement of road embankment was observed and monitored at the field. The results of the total settlement, the maximum excess pore water pressure, and the consolidation time between are shown in Table 3.

Table 1. The physico - mechanical properties of soil layer and filling soil.

\begin{tabular}{|c|c|c|c|c|c|}
\hline Physico- mechanical properties & $\begin{array}{c}\text { Filling } \\
\text { soil }\end{array}$ & $\begin{array}{c}\text { Very soft } \\
\text { soil }\end{array}$ & Clay, stiff & \begin{tabular}{|c|} 
Clay, \\
very stiff
\end{tabular} & $\begin{array}{l}\text { Sand } \\
\text { drains }\end{array}$ \\
\hline Unit weight, $\gamma_{\text {usat }}, \mathrm{kN} / \mathrm{m}^{3}$ & $\begin{array}{c}\text { Mohr } \\
\text { Coulomb }\end{array}$ & $\begin{array}{c}\text { Soft soil } \\
\text { model }\end{array}$ & $\begin{array}{c}\begin{array}{c}\text { Soft soil } \\
\text { model }\end{array} \\
\end{array}$ & \begin{tabular}{|c|}
$\begin{array}{c}\text { Soft soil } \\
\text { model }\end{array}$ \\
\end{tabular} & $\begin{array}{c}\text { Mohr } \\
\text { Coulomb }\end{array}$ \\
\hline Saturated unit weight, $\gamma_{\text {sat }} \mathrm{kN} / \mathrm{m}^{3}$ & 17.6 & 15.9 & 19.7 & 20.1 & 17.6 \\
\hline Vertical permeability coefficient, $k_{y}, \mathrm{~m} /$ day & 20.0 & 16.0 & 19.8 & 20.3 & 20.0 \\
\hline Horizontal permeability coefficient, $k_{x}, \mathrm{~m} /$ day & 0.5 & $4.16 .10^{-4}$ & $1.02 .10^{-5}$ & $2.12 .10^{-5}$ & 10 \\
\hline $\begin{array}{l}\text { Verticla permeability coefficient, } k_{y,} \mathrm{~m} / \text { day (ground } \\
\text { improvement by sand drains }, n=4.5 \text { ) }\end{array}$ & 0.5 & $1.25 .10^{-3}$ & $1.53 .10^{-5}$ & $3.19 .10^{-5}$ & 10 \\
\hline $\begin{array}{l}\text { Horizontal permeability coefficient, } k_{x} \mathrm{~m} / \text { day (ground } \\
\text { improvement by sand drains }, n=4.5 \text { ) }\end{array}$ & 0.5 & $4.16 .10^{-4}$ & $1.02 .10^{-5}$ & $2.12 .10^{-5}$ & 10 \\
\hline Elastic modulus, $E,\left(\mathrm{kN} / \mathrm{m}^{2}\right)$ & 0.5 & $1.11 .10^{-3}$ & $1.53 .10^{-5}$ & $3.19 .10^{-5}$ & 10 \\
\hline Poisson's ratio, $v$ & 30000 & & & & 553.4 \\
\hline Effective friction angle, $\varphi$, degree & 0.30 & & & & 0.30 \\
\hline Effective cohesion, $C^{\prime}\left(\mathrm{kN} / \mathrm{m}^{2}\right)$ & 20 & 19 & 23 & 25 & 30 \\
\hline Dilatancy angle, $\Psi$ (degree) & 1 & 10 & 12 & 14 & 1 \\
\hline Compression index, $C_{c}$ & 0 & 0 & 0 & 0 & 0 \\
\hline Swell index, $C_{r}$ & & 0.90 & 0.15 & 0.11 & \\
\hline initial void ration, $e$ & & 0.20 & 0.03 & 0.02 & \\
\hline Preconsolidation pressure, $P c\left(\mathrm{~T} / \mathrm{m}^{2}\right)$ & & 1.817 & 0.758 & 0.827 & \\
\hline Unit weight, $\gamma_{\text {usat }}, \mathrm{kN} / \mathrm{m}^{3}$ & & 4.5 & 11.0 & 13.0 & \\
\hline
\end{tabular}

Table 2. The parameters of sand drains.

\begin{tabular}{|c|l|}
\hline No & \multicolumn{1}{|c|}{ The parameters of sand drains } \\
\hline 1 & The distance between sand drains, $L=1.8 \mathrm{~m}$ \\
\hline 2 & Diameter of sand drains, $D=0.4 \mathrm{~m}$ \\
\hline 3 & The length of sand drains, $H=14 \mathrm{~m}$ \\
\hline 4 & Sand wells are arranged in an equilateral triangle \\
\hline 5 & The ratio of distance, $n=L / D=4.5$ \\
\hline 6 & The factor depends on the distance between sand drains, $F(n)=n^{2} /\left(n^{2}-1\right) \ln (n)-\left(3 n^{2}-1\right) / 4 n^{2}=0.845$ \\
\hline
\end{tabular}


Table 3. The result of settlement of road in soft soil and after improvement by sand drains (Road embankment constructed with two stages up to $4.8 \mathrm{~m}$ ).

\begin{tabular}{|c|c|c|c|c|}
\hline \multirow[b]{2}{*}{ Parameters } & \multicolumn{2}{|c|}{ Soft soil ground } & \multirow{2}{*}{$\begin{array}{l}\text { Soft soil improvment by } \\
\text { sand drains (Calculating } \\
\text { equivalent plane strain } \\
\text { solution) }\end{array}$} & \multirow{2}{*}{\begin{tabular}{l|l}
$y$ & The field \\
$\mathrm{g}$ & monitoring \\
result at km \\
$3+130$
\end{tabular}} \\
\hline & $\begin{array}{l}\text { Calculating } \\
\text { based on } 22 \mathrm{~T} \\
\text { CN262-2000 }\end{array}$ & $\begin{array}{l}\text { Calculating by } \\
\text { Equivalent plane } \\
\text { strain solution }\end{array}$ & & \\
\hline The total settlement, $U_{y}(\mathrm{~m})$ & 2.083 & 2.024 & 1.801 & - \\
\hline $\begin{array}{l}\text { Excess pore water pressure, } U \\
\left(\mathrm{kN} / \mathrm{m}^{2}\right)\end{array}$ & - & 68.59 & 51.38 & - \\
\hline $\begin{array}{l}\text { The time for degree consolidation } \\
\text { of } 90 \%, t_{90} \text { (day) }\end{array}$ & 16008 & 3450 & 160 & - \\
\hline $\begin{array}{l}\text { The settlement at the construction } \\
\text { time of } 250 \text { days, } m\end{array}$ & - & - & 1.684 & 1.620 \\
\hline
\end{tabular}

From the results in Table 3, the settlement that was determined by equivalent strain plane solution is quite close to the calculation under the Axisymmetric Condition analysis. The simulation results by Equivalent Plane Strain solution was relatively consistent with the results of field observations.

As shown in Table 3, it can be seen that the total settlement of road embankment constructed in soft soil $\left(U_{y}\right)$ was $2.083 \mathrm{~m}$. Otherwise, the total settlement of road embankment constructed in soft soil improvement by sand drains was $1.801 \mathrm{~m}$ and the time requested to achieve 90\% consolidation was 160 days. With a construction period of 250 days, the total settlement was 1.684 $\mathrm{m}$ and the degree of consolidation achieved 93.5\%. After the 250-day construction period, the pore water pressure of the treated ground was reduced from $68.59 \mathrm{kN} / \mathrm{m}^{2}$ (Figure 4) to 51.38 $\mathrm{kN} / \mathrm{m}^{2}$ (Figure 5) and located far from the bottom of the road embankment, so it will not affect to the stability of road embankment (Figure 5). Thus, sand drains was not only shorten construction time but also greatly decrease the settlement of the road embankment.

\subsection{Effect of parameters of sand drains}

When using the Equivalent Plane Strain solution, it is possible to analyze the factors affecting the results of soil soft improvment by sand drains.

\subsubsection{The length of sand drains}

As shown in Figure 6, it can be seen that in case of constant parameters of diameter sand drains $(D=40 \mathrm{~cm})$ and the distance of the sand drains $(L=1.8 \mathrm{~m})$, the increase in the length of sand drains $(H=10 \mathrm{~m}, 14 \mathrm{~m}, 20 \mathrm{~m})$ resulted in decrease in the settlement of ground, the time of consolidation, and the excess pore water pressure.

From the experimental results, it also shown that if the length of sand drains of $14 \mathrm{~m}$ and $20 \mathrm{~m}$, the settlement of ground does not change. When sand drains installed into stiff clay, the settlement of the ground does not decrease. Thus, the sand drains do not need to install into the stiff clay or very stiff clay under soft layer.

\subsubsection{Distance of sand drains}

In case of constant the diameter $(D=40 \mathrm{~cm})$ and the length $(H=14 \mathrm{~m})$ of sand drains, the distance of sand drains changes in three cases $L=$ $1.6 \mathrm{~m} ; L=1.8 \mathrm{~m}$ and $L=2.2 \mathrm{~m}$. Figure 7 shows that an increase in distance of sand drains resulted in an increase in settlement of ground. However, the difference in the settlement between the case $L=$ $1.6 \mathrm{~m}$ and $L=1.8 \mathrm{~m}$ slightly changed. The difference in the settlement between the case $L=$ $1.8 \mathrm{~m}$ and $L=2.0 \mathrm{~m}$ is rather high.

\subsubsection{Diameter of sand drains}

In case of constant the distance $(L=1.8 \mathrm{~m})$ and the length $(H=14 \mathrm{~m})$ of sand drains, the diameter of sand drains changes in three cases $D$ $=30 \mathrm{~cm} ; D=40 \mathrm{~cm}$ and $D=50 \mathrm{~cm}$. As shown in Figure 8, the settlement of ground almost does not change. The results also shows that the increase in the density of soft ground when sand drains constructed has not been noticed in this solution. 


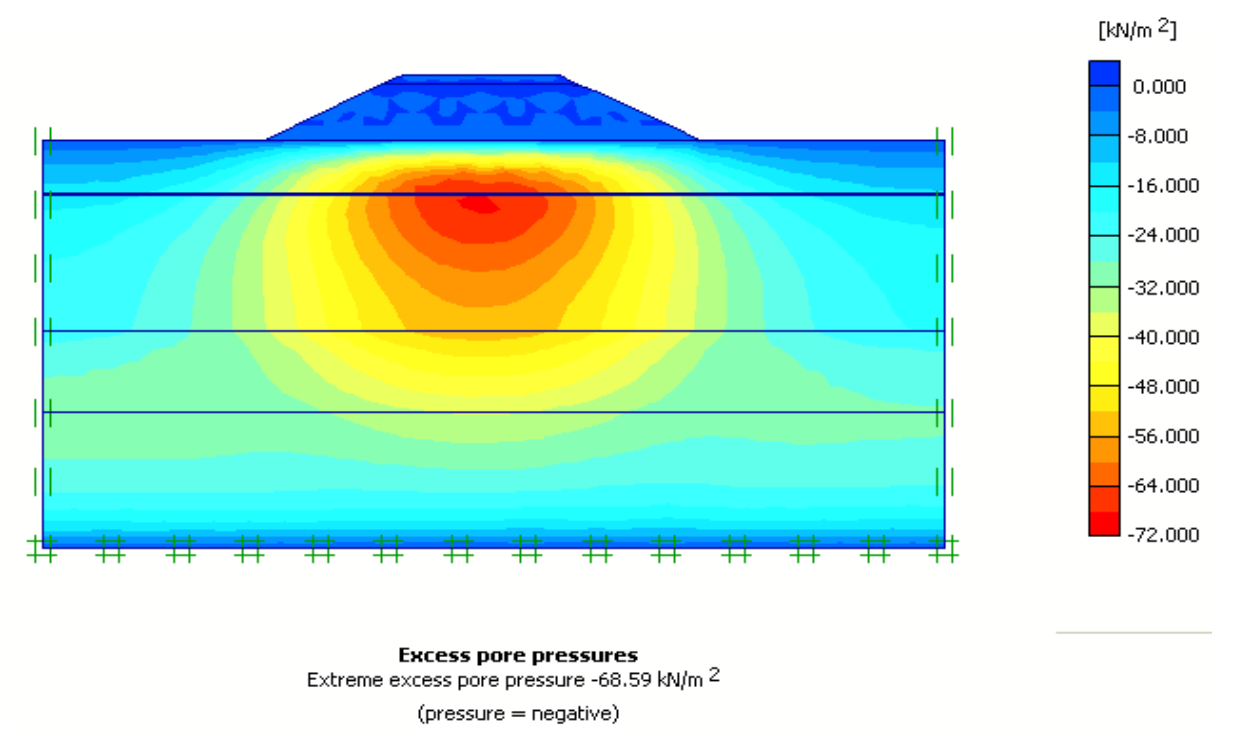

Figure 4. Excess pore pressure in soft ground after construction road without sand drains.

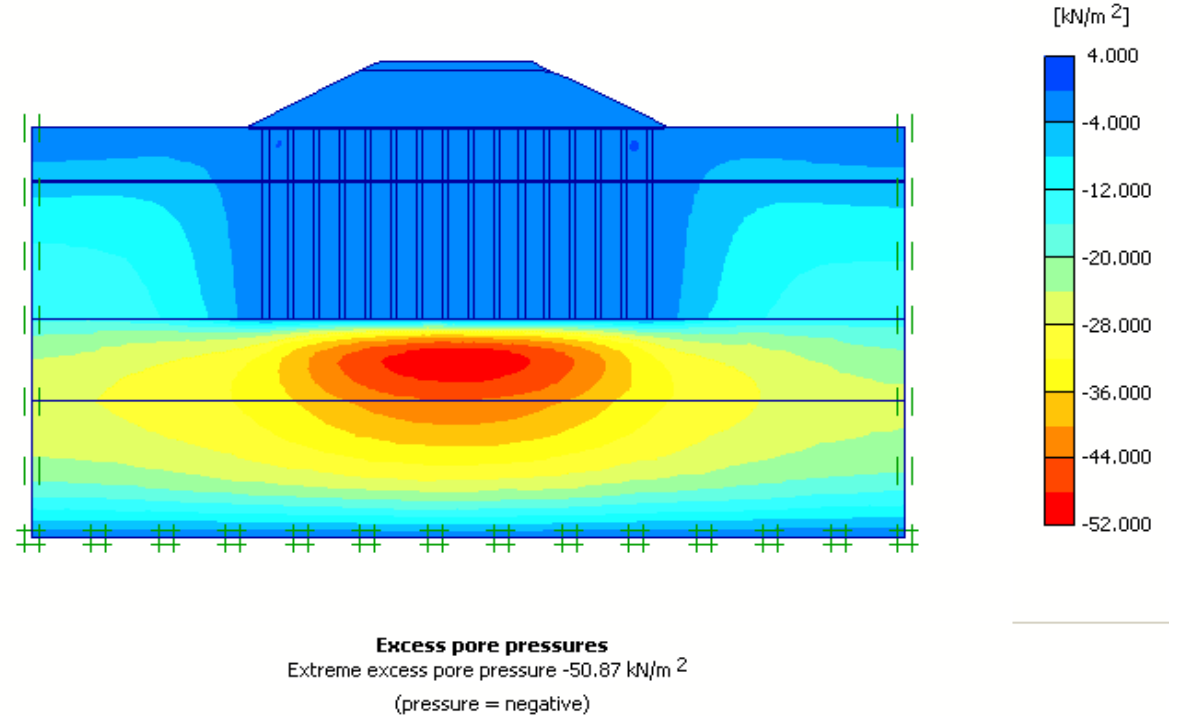

Figure 5. Excess pore pressure in treatment soft ground by sand drains after construction road 250 days.

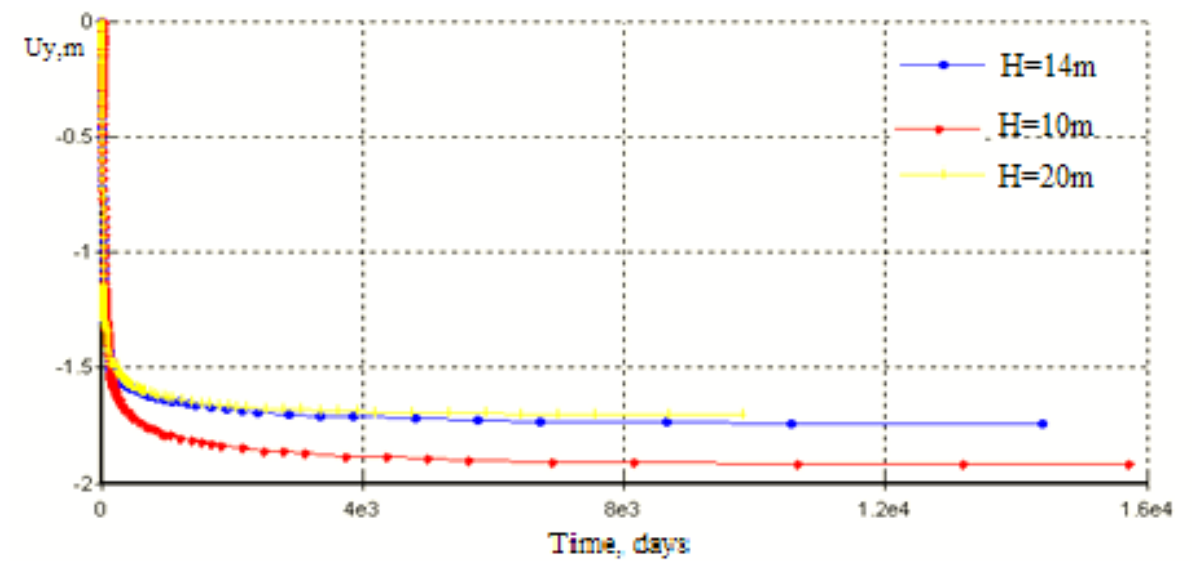

Figure 6. The settlement of ground with different lengths of sand drains. 


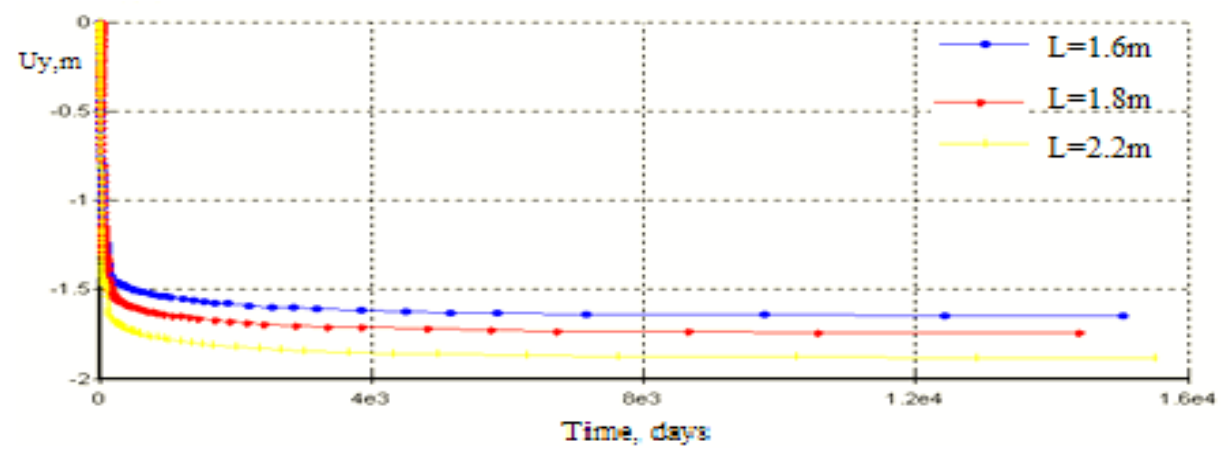

Figure 7. The settlement of ground with different distances of sand drains.

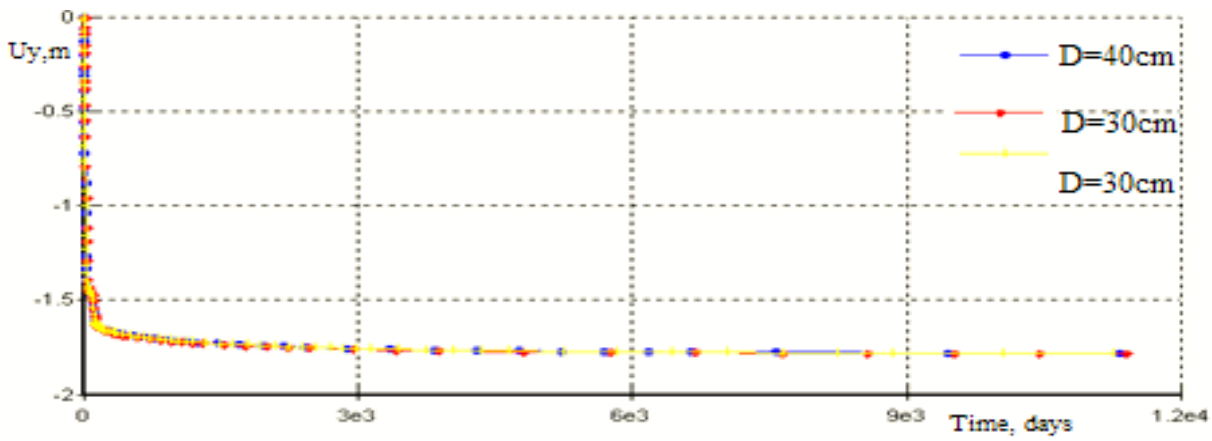

Figure 8. The settlement of ground with different diameters of sand drains.

\section{Conclusion}

To use the Equivalent Plane Strain solution, it is only to convert the horizontal permeability coefficient in the Axisymmetric condition into the horizontal permeability coefficient in the plane condition at the same degree of consolidation.

The Equivalent Plane Strain solution for analysing the soft soil improvement by sand drains can be observed the development of the excess pore water pressure during the construction of road embankment. The length and the distance of sand drains affected on the total settlement and the time of consolidation.

For using the Equivalent Plane Strain solution to design soft soil improvement, the increase in the density of the soft ground during construction of sand drains has not been noticed.

\section{References}

22TCN 262-2000, (2000). Survey and design procedures of highway constructed on soft soil ground.

Barron, R. A., (1948). Consolidation of fine grained soils by drain wells, Proc. ASCE 2346.
718-742.

Brinkgreve, R. B. J., (2002). Plaxis 2D-Version 8 Manual, Balkema.

Hansbo, S., (1981). Consolidation of fine-grained soils by prefabricated drains. Proc. 10th Int. Conf. Soil Mech., Stockholm, Vol. 3, Paper 12/22. pp. 677-682.

Hird, C. C., Pyrah, I. C., Russell, D, (1992). Finite element modeling of vertical drains beneath embankments on soft ground. Geotechnique 42 (3), 499-511.

Hoang Van Tan, Tran Ngo, Phan Dinh Truong, Pham Xuan, Nguyen Hai, (1977). Construction methods on soft ground. Construction Publishers. Hanoi. (In Vietnamese).

Indraratna, B., (2008). Recent advancements in the use of prefabricated vertical drains in soft soils. Australian Geomechanics Journal, March issue, 29-46.

Indraratna, B., and Redana, I. W., (1997). Plane strain modeling of smear effects associated with vertical drains. J. Geotech. Eng., ASCE. 123(5), 474 - 478. 
Indraratna, B., Rujikiatkamjorn C., and Sathananthan, I. (2005a). Analytical and numerical solutions for a single vertical drain including the effects of vacuum preloading. Canadian Geotechnical Journal 42. 994-1014.

Indraratna, B., Rujikiatkamjorn C., and Sathananthan, I., (2005c). Radial consolidation of clay using compressibility indices and varying horizontal permeability. Canadian Geotechnical Journal 42, 1330-1341.

Indraratna, B., Sathananthan, I., Rujikiatkamjorn C. and Balasubramaniam, A. S. (2005b). Analytical and numerical modeling of soft soil stabilized by PVD incorporating vacuum preloading. International Journal of Geomechanics 5 (2). 114-124.

Nguyen Thi Nu and Phi Hong Thinh, (2020). Soft soils in the Me Kong Delta of Vietnam. ActuAlscience 4(1), 24-31.

Nguyen Thi $\mathrm{Nu}$, (2014). Researching of engineering geological properties of soft clayey soil amQ22-3 distribution in the coastal provinces of Mekong delta for ground improvement for road construction. Doctoral thesis in Geology. Ha Noi (In Vietnamese).

Nguyen Thi $\mathrm{Nu}$, (2016a). Geotechnical properties of soft clayey soil in the amQ22-3 formation in the coastal provinces of Mekong Deltal for road construction. Journal of Mining and Earth Sciences 6-10. 49-57

Nguyen Thi $\mathrm{Nu}$, (2016b). Design approval for soft soil ground using prefabricated vertical drains and combination of vacuum preloading. Journal of Mining and Earth Sciences, 30/08/2016. 46-54. (In Vietnamese).

Nguyen Thi $\mathrm{Nu}$, Bui Truong Son, Do Minh Ngoc. (2019). An Experimental study of reusing coal ash for base course of road pavement. Electronic Journal of Geotechnical Engineering 24(4), 945-960.

Nguyen Thi Nu, Bui Truong Son, Pham Van Hai. (2020a). Utilisation of ground granulated blast furnace slag (GGBFS) for soft soil improvement by deep mixing method. Journal of Mining and
Earth Sciences 61 (1). 92-100. (In Vietnamese).

Nguyen Thi Nu, Do Minh Toan, Nguyen Viet Tinh, (2011). Determining the parameters of consolidation of amQ22-3 soft to very soft clay (CL, CH) distributed in Soc Trang area for calculating settlement of soil and ground improvement by vertical drains method. Journal of Mining and Earth Sciences 35/07/2011. 32-39. (In Vietnamese).

Nguyen Thi $\mathrm{Nu}$, Nguyen Thanh Duong, Nguyen Van Phong (2019). The effects of salt contents on the geotechnical properties of some soft soils in the coastal area of Vietnam. Journal of Mining and Earth Sciences 60 (6), 51-60.

Nguyen Thi, N., Thinh, P. H., Son, B. T, (2019). Utilizing coal bottom ash from Thermal Power Plants in Vietnam as partial replacement of aggregates in concrete pavement. Journal of Engineering, 2019

Nhu Viet Ha, (2020). Challenges and approaches in three-dimensional modeling the engineering geological conditions of Hanoi area. Journal of Mining and Earth Sciences 61 (2). 1-9.

Nu, N. T., Toan, D. M., Thinh, P. H, Son, B. T., (2020b). Determination of Particles and Minerals Content in Soft Clay Soil of the Mekong Delta Coastal Provinces, Southern Vietnam for Inorganic Adhesives Stabilization. Determination of Particles and Minerals Content in Soft Clay Soil of the Mekong Delta Coastal Provinces, Southern Vietnam for Inorganic Adhesives Stabilization. Iraqi Journal of Science 61(4). 791-804.

Perera, D., Indraratna, B., Leroueil, S., Rujikiatkamjorn, C., \& Kelly, R., (2017). Analytical model for vacuum consolidation incorporating soil disturbance caused by mandrel-driven drains. Canadian Geotechnical Journal 54(4). 547-560.

Tavenas, P., Jean, P., Leblond, P., and Leroueil, S, (1983). The permeability of natural soft clays. Part II: permeability characteristics. Canadian Geotechnical Journal 20. 645-659. 